\title{
Face-Threatening Acts: Conflict between a Teacher and Students in EFL Classroom
}

\author{
I-Ju Chen \\ Ling Tung University, Taiwan \\ Email: littlebear9152008@yahoo.com.tw
}

How to cite this paper: Chen, I. J. (2017). Face-Threatening Acts: Conflict between a Teacher and Students in EFL Classroom. Open Journal of Modern Linguistics, 7, 151-166.

https://doi.org/10.4236/ojml.2017.72012

Received: March 12, 2017

Accepted: April 17, 2017

Published: April 20, 2017

Copyright $\odot 2017$ by author and Scientific Research Publishing Inc. This work is licensed under the Creative Commons Attribution International License (CC BY 4.0).

http://creativecommons.org/licenses/by/4.0/

(c) (i) Open Access

\begin{abstract}
As traditional concept of Chinese value and personality, the issue of face plays a vital role in Chinese culture not only in daily life but also in learners' learning context. This study investigates English teachers' use of threatening acts in EFL classrooms. One female EFL teacher of the junior high school and her 49 EFL students participated in the present study. With the use of classroom observation, the teacher interview and students' open-ended questionnaires, 38 threatening acts and 4 main threat types (indirect threats, indirect accusation, direct threats with modified blame, and direct threats with explicit blame) were noted. The factors affecting the teacher's use of threatening acts and students' responses and opinions toward the teacher's use of threats were discussed. The pedagogical implications were provided at the end of the study.
\end{abstract}

\section{Keywords}

Face, Threatening Acts, EFL Students, Indirect Threats, Indirect Accusation

\section{Introduction}

\subsection{Background and Rationale}

The major concerns tackled in classroom-oriented research may be related to teachers' teaching effectiveness and students' learning outcomes. Allwright and Bailey (1991) investigated what constituted effective teaching and stated the requirement of incorporating the findings into effective teacher training in classroom research. It was found that teacher talk plays a major role in teaching and learning in classroom settings and comprises a significant part of classroom instruction (Dörnyei \& Murphey, 2003; Bishop \& Glynn, 1999; Brown, 2007, as cited in Agustina \& Cahyono, 2016). From this perspective, Chaudron (1988: p. 6) indicated that learning can be facilitated when the classroom provides the learners with "comprehensible target language input in an affectively supportive 
climate." Nevertheless, in classroom settings, the teacher (speaker) is clearly more powerful in some sense than the students (hearer). The climate of a classroom is not always supportive and sometimes even conflictive. Cole (1988) stated that in numerous situations, the speaker may not care whether the effect of a face-threatening act (FTA) is redressed. The classroom environment is one of the most suitable examples, where the speaker (the teacher) may use a bald-on-record utterance. Such a relationship might be that of masters and servants, or more commonly, of employers and employees.

Threatening is a speech act that has received the least attention in the field of pragmatics. Chen (2006) indicated that research examining impoliteness has been scant. However, the dynamics of impoliteness in interaction may expand our knowledge regarding the complexities of this phenomenon. The effects of the various factors on a speaker's choice of strategies have been the main concern of numerous studies on various speech acts, such as apologies, requests, complaints, refusals and disagreements (Blum-Kulka, 1982; BlumKulka \& Olshtain, 1984; Pomerantz, 1984; Beebe \& Cummings, 1985 as cited by Chen, 2006). Few interlanguage studies have reported on disagreement (Beebe \& Takahashi, 1989a, 1989b; Takahashi \& Beebe, 1993, as cited by Chen, 2006), on refusing or providing embarrassing information (Nakajima, 1997, as cited by Chen, 2006), and on teachers' threatening behavior in EFL classrooms (Chen, 2006). As Graham (2007) suggested, the recent studies in the politeness theory have refined the framework of Brown and Levinson (1987) to be more applicable to a wider range of circumstances. By examining the FTAs of the EFL classroom, not only researchers but also English teachers may obtain insight into English teaching behavior from a pragmatic perspective (Bouchard, 2011).

Since the mid-1960s, researchers have suspected that anxiety inhibits foreign language learning. Although several studies have claimed that some tension can motivate students and enhance their learning (Sielmann \& Radnofsky, 2001, cited by Ewald, 2007), numerous studies have emphasized the negative effects of anxiety in the classroom (Horwitz, 1995; Gregersen \& Horwitz, 2002; Gregersen, 2003; Klkhafaifi, 2005, cited by Ewald, 2007; Tseng, 2015). As Ewald (2007) suggested, to promote nonthreatening learning environments for students in class and to relieve students' anxiety, teachers can build a friendly, supportive learning environment and present themselves as helpful instructors concerned with promoting students' learning rather than authority figures concerned with evaluating student behavior (Brophy, 1999; Gregersen \& Horwitz, 2002, as cited in Ewald, 2007). However, although most experienced language teachers recognize that anxiety is not a positive ingredient for successful learning in the teaching process, some still believe students' unfavorable behavior in class needs to be prohibited by using certain verbal threats. These circumstances may cause conflict between the teacher and students; various teachers argue for conflicting beliefs regarding whether or not teachers ought to use threatening acts in class. 


\subsection{Purposes of the Study and Research Questions}

This study explores one English teacher's use of threatening acts in EFL classrooms. In addition, students' perceptions of the use of threatening acts by teachers are determined. To achieve the goals, the researcher adopted qualitative methods to address the following research questions:

1) What are the threatening acts used by EFL teachers in class?

2) What are the patterns of the teacher's use of threatening acts?

3) What are the factors affecting EFL teachers' use of threatening acts?

4) What are the students' responses and their perceptions of the teachers' use of threatening acts in EFL classrooms?

\section{Literature Review}

\subsection{FTAs}

Scollon and Scollon (1995: p. 38) claimed that "there is no faceless communication." Brown and Levinson (1987) further indicated that every speech act is a FTA. Brown and Levinson (1987) also stated that all speech acts are FTAs jeopardizing the solidarity between the speaker and the addressee and proposed four FTA types-FTA performed baldly with no politeness (e.g. "Close your mouth when you eat, you swine"), FTA with positive politeness (e.g. "You have such beautiful teeth. I just wish I didn't see them when you eat”), FTA with negative politeness ("I know you're extremely hungry and the steak is a bit tough, but I would appreciated it if you would chew with your mouth closed"), and FTA that is indirect or off-record ("I wonder how far a person's lips can stretch yet remain closed when eating"). An indirect FTA is ambiguous so the receiver may catch the drift, but the speaker can also deny the meaning if they wish. In fact, performing an act baldly, without redressive action, involves performing it the most directly, clearly, unambiguously, and concisely. Performing an act with redressive action implies giving face to the addressee by using positive or negative politeness. By using positive politeness, a person may be showing that he or she is interested in something that another person presumably finds desirable. By using negative politeness, a person may attempt to partially satisfy another person's desire to be imposed upon by implying that he or she does not think another person can do something for him or her. Moreover, Buck (1994) claimed that orders and requests may threaten a hearer's desire to be left alone, whereas the acts of criticism, disapproval, and disagreement threaten the hearer's desire to be liked and respected. Therefore, these linguistic acts may be inherently threatening the hearer, potentially becoming the principal unit of FTA. Hiraga and Turner (1996) indicated that according to Brown and Levinson's formulation, the predominant illocutionary force, such as criticism, suggestion, or request, may be expected to threaten both the positive and negative face of the students. More recently, Jaszczolt (2002) indicated that FTAs refer to the interaction of conversations, in which interlocutors may threaten each others' and their own face by making requests and suggestions, by criticizing and advising, or by expressing guilt and thanks. Most speech acts performed by speakers are 
potentially face-threatening. FTAs can threaten a person's positive face, which indicates personality and includes the desire that the person's self-image is approved or appreciated. Threatening hearers' positive face covers the expressions of disapproval, criticism, contempt, complaint, accusation, insult, disagreement, and violent emotion; mention of taboo topics; interruption and other non-cooperation; and conveying bad news about the hearer or good news about the speaker. FTAs can also threaten the negative face, including the basic claim to personal possessions and private space as well as rights to nondistraction, freedom of action, and freedom from imposition. Threatening hearers' negative face includes orders; requests; suggestions; advices; reminders; threats; warnings; offers; promises; as well as expressions of envy, admiration, hatred, anger, and lust. Some FTAs may threaten both aspects of the face; the distinction between threatening the negative and positive faces is only approximate. Moreover, the faces of both the speaker and the hearer can be threatened. The speaker can threaten his or her own face by expressing gratitude or apology. As Jaszczolt (2002) asserted, FTAs can be performed either directly (on record) or indirectly (off record). Going on record gives the speaker credit for honesty, and he or she is considered trustful, whereas going off record makes the speaker appear tactful as his or her utterance is ambiguous, with more than one attributable intentions. Going on record, along with positive or negative politeness, leads to the strategies of positive or negative politeness. Positive politeness can be realized as suggesting commonality, understanding, and joint action, whereas negative politeness is expressed by showing respect and maintaining social distance. On record FTAs can be divided into those with and without redressive action. The term FTA with redressive action refers to being of either positive or of negative politeness type, addressing the need to be approved of or the need to be left free from imposition. All speakers have a face, which they want to maintain; they also want to maintain the addressees' face. Therefore, for performing FTAs, the speakers attempt to minimize the face threat, unless the need to execute FTAs with maximum efficiency is greater than the need to preserve face.

Simmons (1994) claimed that politeness, the act of considering others' feelings, is achieved through verbal strategies. To avoid the aforementioned FTAs, we may employ politeness strategies in our interaction. Brown and Levinson (1987) also classified different types of politeness strategies for reacting to FTAs. The different politeness strategy types follow three sociological factors: the relative power of the hearer over the speaker, the social distance between the speaker and the hearer, and the ranking of the imposition in performing the FTA. We can respond with either of two strategies when a FTA is involved in an interaction. If we decide to perform it, we can perform the FTA either directly (on record) or indirectly (off record). If we perform it without considering the hearer, we perform the FTA baldly. To reduce the face-threatening effect on the hearer, we may use positive politeness, in which the speaker tries to save the hearer's positive face by reducing the distance between them, or negative politeness, in which the speaker tries to keep the hearer's negative face by valuing the hearer's personal territory. Moreover, Jaszczolt (2002) indicated four strategies 
that may be used to avoid FTAs: bald on record, on record with positive politeness, on record with negative politeness, and bald off record strategies. First, the bald on record strategy involves speaking in conformity with Grice's Maxims by using direct imperatives where face threat need not be moderated. Welcomes, farewells, and offers can be expressed in this way. Second, the on-record with positive politeness strategy involves an act that is performed directly with an expression or form of appreciation of the hearers' wants or an expression of similarity of the speaker's and the hearer's wants. This strategy includes claiming common ground, such as seeking agreement, asserting common ground, and joking; conveying cooperation between the speakers and the hearers; and fulfilling the hearer's want for something, such as verbal gifts of understanding and sympathy. Third, the on record with negative politeness strategy results in respectful behavior, thus respecting the hearers' wants to have their freedom unhindered. It minimizes the imposition of the FTAs. Substrategies of this strategy include assuming that the hearers are unlikely to be willing or able to perform any acts predicated of them, being pessimistic, providing deference as well as minimizing the imposition, and communicating the want not to impinge on the hearers, impersonalize the speakers and the hearers. As Dogancay-Aktuna and Kamisli (1996) stated, negative politeness may be considered less threatening than positive politeness because positive politeness is based on the assumption that the hearers agree with the speakers' assertions of their closeness and this assumption may not necessarily be shared by the hearers. Fourth, the strategy of performing the FTA off record may group the utterances in which attributing a clear communicative intention to the speakers is impossible. The act is typically indirect and the hearers must perform some inference to recover what was intended. The classic off-record strategies are the use of metaphor, irony, understatement, or rhetorical questions. Therefore, to reduce the possibility of damaging the hearers' faces or the speaker's own face, interlocutors may adopt certain strategies. The choice of strategy will be made on the basis of the speaker's assessment of the severity of the FTA. The first decision is regarding whether FTAs should be performed. If the speaker decides to perform them, four possibilities can be used: three sets of on-record superstrategies [performing FTAs on record without redressive action (bald on record), on record by using positive politeness, and on record by using negative politeness] and one set of off-record strategies. By contrast, if the speaker decides that the degree of face threat is too high, he or she may avoid FTAs altogether. Recently, Hatipoglu (2007) concluded that polite behavior can be defined as the use of verbal or nonverbal strategies that consider the hearers' feelings by showing concern for their face needs. Face is a universal notion constituted by two basic desires: need to not be imposed upon (negative face concerns) and need to be appreciated and approved of (positive face concerns).

\subsection{Power and Solidarity}

Researchers indicated that power and solidarity capture the way we juggle involvement and independence in the real world (Tannen, 1986; Tsuda, 1993). 
Power refers to control over others, an extension of involvement and resistance to being controlled; power is an extension of independence; power serves the desire not to be imposed upon. In fact, "power may masquerade as solidarity" (Tannen, 1986: p. 94, cited by Tsuda, 1993). Thus, indirectness may also damage communication when used only for selfish aims of manipulating others. For example, in a society where people are sensitive to the rank order of the people, indirectness is often employed by people of higher status to control people of lower status. Brown and Levinson (1987) stated "joking is a basic positive-politeness technique." It seems that joking is used for people to feel that they share the same values; people make jokes to each other to maintain each other's positive face. Indirectness can be used to maintain the face of the speaker and the hearer; joking may be used to relieve tension. Brown and Levinson (1987) stated that talks among interlocutors may require softening devices to facilitate conversations. However, it was revealed that, among close Chinese friends, informal conflict talks were intended to establish or enhance rapport and in-group solidarity. Under these circumstances, social contexts, such as the formality of a situation and the participants' relationships, were important variables in Chinese people's communicative behaviors (Kuo, 1992, cited by Chen, 2006). In their review of Kuo's (1994) study, Chen (2006) also proposed that a speaker's social identity determined his or her choice of politeness strategies. The less powerful a speaker was in the conversation, the more frequently that speaker used politeness strategies. In contrast, the more powerful a speaker was, the more direct and confrontational that speaker's politeness strategies were.

\subsection{Summary}

Speech act studies have been flourishing in the field of pragmatics. However, research on FTAs in classroom settings, particularly the highly face-threatening speech act behavior, remains insufficient. Furthermore, studies on FTAs have included discourse analysis or have analyzed the effects of social status on strategies used within the face and politeness framework. Thus, additional studies investigating FTAs in EFL teaching environments and students' responses to such acts are required. Finally, the threatening behavior of an EFL teacher in relation to "face", "face-work", or "politeness" could be instruments that might supply richer insights into social values and perceptions of teachers from different social contexts and reflect different sociological and psychological factors.

\section{Methodology}

The present study investigated the types, the patterns, and the factors of threatening acts of a junior high school EFL teacher as well as students' responses and perceptions of such acts. By using research methods derived from classroom observation, a face-to-face interview, and an open-ended questionnaire, the questions of what, how, and why regarding this junior high school EFL teacher's use of threatening acts in class can be addressed. Also the junior high school EFL 
students' responses and perceptions of these acts can be studied.

\section{Subject Selection}

\section{The Setting}

A private high school is located in northern Taiwan, with a total of approximately 3700 students and 34 and 40 classrooms of junior and senior high school divisions, respectively. A total of $29 \mathrm{EFL}$ teachers are responsible for English teaching in both high school divisions. The school follows the Curriculum Standards proposed by the Ministry of Education.

The teacher:

Among 29 EFL teachers in the target school, one female EFL teacher of the junior high school division (age, 31 years) was selected by random sampling in this study. The teacher learned English for more than 15 years, and obtained a master's degree in English literature from a public university located in southern Taiwan. After graduation from a private university in central Taiwan, the teacher with the major of English attended a graduate school and earned the required credits for teaching training courses in graduate school; that is, took education credit classes for one year to obtain the required credentials for being a teacher. The teacher then served as a practice teacher for one year in this school before she became a qualified English teacher. The teacher taught English for more than four years. To protect the teacher's privacy, her name in the study was the pseudonym "Teacher A".

Students:

A total of 49 students from one class taught by Teacher A participated in this study. Class 85 was a third grade, co-ed class, with 26 girls and 23 boys, receiving a 6-hour English course per week with the textbook edited by Kang-Hsian Publishers. The teaching of Lessons 2, 3, and 4 of Book 6 were observed during the data collection process. The students in Class 85 were active and willing to respond to their teacher's questions positively. Although students' attitudes toward learning were positive, some male students were sometimes unfocused and others were talkative during the class. In this situation, Teacher A spent some time in managing the class.

\section{Data Collection}

Because this study investigated the types, patterns, and factors of threatening acts of the junior high school EFL teacher as well as students' responses and perceptions of such acts, data were gathered through classroom observation, an unstructured interview, and an open-ended questionnaire. First, classroom observation was performed, followed by open-ended questionnaire administration to the students. Finally, Teacher A was interviewed on the basis of classroom observation data. After collection, data were transcribed, coded, and analyzed.

Open-ended Questionnaire:

The open-ended questionnaire covered questions about students' perceptions 
on general classroom learning atmosphere, satisfication of overall teaching styles, and their preferences of teachers' expression during the classroom. Forty-nine EFL students were asked to answer the open-ended questionnaires right after the class. The questionnaire was administered to triangulate the researcher's observation and the face-to-face teacher interview results.

Classroom Observation:

Before observing the classroom, the researcher sought the teacher's permission for classroom observations with a video camera and tape recorders. The researcher then checked and arranged the observation schedule with Teacher A. The teacher was asked not to make any change in her teaching process, so that the actual classroom behavior can be observed. The teacher was observed for three lesson units. All classroom observations were videotaped and audiotaped. All 10 collected 45-minute tapes were transcribed verbatim, making them the major source for data analysis.

Unstructured Interview:

After classroom observation and open-ended questionnaire administration, Teacher A was interviewed in depth to obtain more detailed information on the basis of the observation data of the teacher's classroom instruction. The interview aimed to understand the reason that she used certain FTAs in class and thus to explore more deeply the teaching rationale of these acts. The interview, spanning approximately 1 hour, was audiotaped and transcribed into written form for analysis.

\section{Data Analysis}

Three instruments, namely classroom observation, an open-ended questionnaire, and an unstructured interview, were analyzed according to the study purposes and research questions.

Analysis of Classroom Observation:

Data obtained from classroom observation was first transcribed verbatim and then analyzed qualitatively. Next, the researcher categorized and coded data in terms of types and functions of threatening behavior. Meanwhile, the frequencies of occurrence of certain types and functions were computed with descriptive statistics. Furthermore, to evaluate the possible patterns of threatening acts, these types and functions were compared across different contexts.

Analysis of Questionnaire Responses:

The responses to the open-ended questionnaire were analyzed to understand the students' perceptions of the teacher's FTAs in the junior high school EFL classroom. The responses were analyzed, categorized, and computed with descriptive statistics.

Analysis of Interview Data:

The teacher's interview data were recorded, transcribed, and analyzed qualitatively. This retrospective interview explored the teacher's teaching beliefs regarding the use of certain threatening acts. The interview data were defined, categorized, and synthesized; different functions of such acts were theorized. 


\section{Results and Discussion}

The present study explored the types, patterns, and factors of threatening acts of junior high school EFL teachers. In addition, students' responses and perceptions of such acts were also investigated. To answer the research questions, the results were reported on the basis of data obtained from classroom observation, teacher interview, and students' questionnaire.

\subsection{Types of Threatening Actions Taken by Teacher A}

A total of 38 threatening acts were found. Specifically, these threats could be categorized into four main types of threats: 1) indirect threats (avoiding explicit mention of the students), 2) indirect accusations (involving questions to students about their unfavorable behavior), 3) direct threats with modified blame (with softer expression), and 4) direct threats with explicit blame. The results indicated that the teacher adopted both indirect and direct threats to students in class. In total, 16 (42.5\%) examples of indirect threats, 9 (23.7\%) of direct threats with explicit blame, $8(21.1 \%)$ of direct threats with modified blame, and 5 (13.2\%) of indirect accusation were identified. The researcher implied that the teacher preferred using indirect threats (55.7\%) compared with direct threats (44.8\%). The finding corroborates the statement of Tsuda (1993: p. 66): "indirectness is preferred to two main reasons: to save face if conversational contribution is not well received, and to achieve the sense of rapport that comes from being understood without saying what one means." Table 1 lists the average frequencies of each threat type in each class.

The teacher used different types of threats in every observed class hour. Her threats were observed to be used more frequently in the fourth hour of the class, including 7 indirect threats, 6 direct threats with explicit blame, 3 indirect accusations, and 2 direct threats with modified blame. Therefore, students' unfavorable behavior may increase during certain class time prompting the teacher to use threats more frequently to prevent such acts. The use of more direct threats potentially conforms with Pazey's (1994) as well as Brown and Levison's (1987) idea of schematic set of strategies that a FTA can be performed baldly without regressive action when fear of retribution from the addresses does not exist, except in three circumstances: when the danger to the hearer's face is extremely small, when it is in his or her best interest, and when the speaker is more powerful than hearer or has the ability to enlist audience support to destroy hearer's face without losing his own.

\subsection{Patterns of Teacher's Threatening Acts}

Four patterns of the teacher's use of threatening acts were observed across different classroom sections. First, both indirect and direct threatening acts were used by the teacher. In each class hour, the teacher used both indirect and direct threats to prevent students' unfavorable behavior. In the first observed class, one indirect threat and one direct threat with explicit blame were used simultaneously (see Excerpt 1). Second, threatening acts seemed to have priority pat- 
Table 1. Frequency distribution of threat types in each class.

\begin{tabular}{|c|c|c|c|c|}
\hline Types of Threats & Class & Hour & Occurrence & Percentages \\
\hline \multirow[t]{9}{*}{ Indirect threats } & 1 & 2 & 1 & $2.6 \%$ \\
\hline & 2 & 3 & 3 & $7.9 \%$ \\
\hline & 2 & 4 & 1 & $2.6 \%$ \\
\hline & 3 & 2 & 1 & $2.6 \%$ \\
\hline & 4 & 5 & 1 & $2.6 \%$ \\
\hline & 5 & 4 & 2 & $5.3 \%$ \\
\hline & 6 & 2 & 1 & $2.6 \%$ \\
\hline & 7 & 3 & 2 & $5.3 \%$ \\
\hline & 7 & 4 & 4 & $10.5 \%$ \\
\hline Total amount of indirect threats & & & 16 & $42.1 \%$ \\
\hline \multirow[t]{3}{*}{ Indirect accusation } & 2 & 3 & 2 & $5.3 \%$ \\
\hline & 2 & 4 & 2 & $5.3 \%$ \\
\hline & 5 & 4 & 1 & $2.6 \%$ \\
\hline Total amount of indirect accusation & & & 5 & $13.2 \%$ \\
\hline \multirow[t]{5}{*}{ Direct threats with modified blame } & 2 & 3 & 1 & $2.6 \%$ \\
\hline & 4 & 5 & 1 & $2.6 \%$ \\
\hline & 6 & 2 & 1 & $2.6 \%$ \\
\hline & 7 & 3 & 3 & $7.9 \%$ \\
\hline & 7 & 4 & 2 & $5.3 \%$ \\
\hline \multicolumn{3}{|c|}{ Total amount of direct threats with modified blame } & 8 & $20.1 \%$ \\
\hline \multirow[t]{6}{*}{ Direct threats with explicit blame } & 1 & 2 & 1 & $2.6 \%$ \\
\hline & 2 & 4 & 2 & $5.3 \%$ \\
\hline & 3 & 2 & 1 & $2.6 \%$ \\
\hline & 5 & 4 & 1 & $2.6 \%$ \\
\hline & 6 & 2 & 1 & $2.6 \%$ \\
\hline & 7 & 4 & 3 & $7.9 \%$ \\
\hline \multicolumn{3}{|c|}{ Total amount of direct threats with explicit blame } & 9 & $23.7 \%$ \\
\hline \multicolumn{3}{|l|}{ Total threats } & 38 & $100 \%$ \\
\hline
\end{tabular}

tern: indirect threats were used before direct threats. From the observed data, the teachers tended to use indirect threats, avoiding explicit mention of the students first, followed by indirect accusation (see Excerpt 2), direct threats with modified blame (see Except 3), or direct threats with explicit blame (see Excerpt 4). Moreover, indirect accusations were used before direct threats with explicit blame (see Excerpt 5). Third, the threatening acts appeared to be used from weaker to stronger tones (see Excerpt 6). When the teacher used direct threats with explicit blame, a request appeared, followed by nagging and anger. This pattern may corroborate the assertion of Boxer (2002) that nagging is explicated as both a speech event and a speech act that is a part of a larger event. Nagging is 
a speech event incorporating several sequential acts: the first move is request. When request is repeated it becomes a reminder. When a reminder is repeated, it becomes nagging. Thus, nagging requires a prior request and reminder, and these acts are sometimes repeated more than once. Nagging, often bald on record, finally becomes a type of exclamation that expresses exasperation. Therefore, a final culminating speech act in nagging even can either be a scolding or anger. Finally, the use of threatening acts appeared to be a reciprocal event between the students and the teacher. According to Jaszczolt (2002), the acts threatening the hearers' positive face include expressions of disapproval, criticism, contempt, complaint, accusation, insult, disagreement, violent emotion, mention of taboo topics, interruption and other noncooperation and providing bad news about the hearers or good news about the speaker. Furthermore, the acts threatening the hearers' negative face include orders, requests, suggestions, advice, reminders, threats, warnings, offers, promises as well as expressions of envy, admiration, hatred, anger, and lust. In the current classroom settings, students appeared to threaten Teacher A's positive face first by certain unfavorable behavior by interrupting the teacher's teaching process or other noncooperation behavior. The teacher then adopted certain forms of reminders, threats, warnings, or requests to threaten students' negative face; for example, falling asleep, eating during class, chatting with others, passing written notes during class, lying on the top of the desk, or other unfavorable behavior were seen as the acts that may interrupt teacher's teaching process or considered noncooperation in class. In such conditions, a teacher may adopt different levels of threatening acts to prevent such behavior.

Excerpt 1: "Those who are seated in the back are not paying attention to the class."

Excerpt 2: “Do I need to wake you up? Don't you know it's time for class? Wu-Wei Lai! Sit still! A-Town! Get up!"

Excerpt 3: "I can't believe it! To my surprise, A-Ting passes written messages with other students in my class!"

Excerpt 4: "Yun-Wen Huang! Three-Two-One! No answer! Answers are shown in your textbook! You still don't know what the answer is!"

Excerpt 5: "You are crazy because you are acting like a woman!"

Excerpt 6: "Yen-Ling Chen! If you are sleeping right now, you won't want to sleep after lunch! Now, I am telling you not to sleep right now! Sit still! Like this word 'waste'. Like a waste!"

\subsection{Factors Affecting Teacher's Use of Threatening Acts}

After interviewing the teacher, different factors affecting the teacher's use of threatening acts were evaluated. Among the four main threat types, eight were identified: students' unfavorable behavior, students' gender, teacher's role, teacher's personality, teacher's familiarity toward students, teacher's belief, class time, and school standards. As for the first factor, both observation and interview data indicated that when the teacher's teaching process was interrupted by 
certain unfavorable behaviors of the students in class, such as sleeping, eating, chatting, or violation of other classroom regulations, the teacher used threats. When students violated such regulations several times, the teacher's use of the threats became more direct (see Excerpt 7). The second factor was students' gender. As indicated by both observation and interview data, the teacher used more threats to male students than female ones (see Excerpt 8 ). The third factor concerns the teacher's dual roles in class. Because the observed teacher is an English lecturer as well as the classroom advisor, much more attention was put on students' bad manners in class, such as dress or using disposable chopsticks (see Excerpt 9). The teacher's impatient or irritable personal comments were the fourth factor affecting the use of threats (see Excerpt 10). The fifth factor was the teacher's familiarity toward students. Furthermore, the teacher used threats toward more familiar students than toward less familiar ones (see Excerpt 11). The sixth factor was the teacher's belief of the effectiveness of threats (see Excerpt 12). The seventh factor, class time, may also have a critical role affecting the teacher's use of threats. As shown in the observation data, the phenomenon that the teacher's threats appeared more frequently in the fourth hour of the classroom implied that the students' unfavorable behavior increased during certain class time so that the teacher's threats may have been used more frequently to prevent such acts. The same tendency was noted in the interview data (see Excerpt 13). The final factor affecting the teacher's use of threats was the school standards; the supervising system during class time may promote the teacher's use of threats toward their students (see Excerpt 14). The supervisor may send emails to inform the teachers whose classes are under control and ask them for improvement; this appears to be an indirect threat to the teacher from the school. In this situation, such a threat may foster the teacher's use of threats in class. Such factors may echo Buck's (1994) assertion that factors extrinsic to language may affect the conversational strategies responding to FTAs. The social distance between participants (regardless of them being strangers, acquaintances, friends, or intimates) influences their choices, as does their relative social power (freedom to impose on another's desires for face that derive from the factors of gender, age, culture, wealth, or class). More specifically, the factors found in the present study also corroborate the assumption of Peng et al. (2014), which indicates that teachers bring on great distance in the classroom context as still some of the teachers enjoy authority over students.

Excerpt 7: "I usually use a softer tone; if it is useless, I use a stronger tone or threats! Students' violations of the school regulations must be the main factor, and when violations appear several times, it's time to use threats!"

Excerpt 8: "Yun-Way Lai sit still! A-Taun! Get up!" "Wei-Ren Chiang! Is it ridiculous to sleep in class like you do?", "Chan-Chi Tai, are you Kai-Ting Huang?" and "You are crazy for being a woman!"

Excerpt 9: "Because I am an advisor of this class, I may consciously pay attention to their dress. I think this is because of the role of the advisor ... In other classes, I will not do so, unless someone does not pay attention to the lecture or 
affect my teaching process!"

Excerpt 10: "I never knew that I am so fierce! If somebody affects or interrupt my teaching process through noise, I don't feel good!"

Excerpt 11: "I am familiar with Class 94, so if they clamor in class, I will threaten them! Threats may be used in more familiar classes, but if I use threats in an unfamiliar class, the tension will be increased!"

Excerpt 12: "Using threatening acts is more effective because for unsatisfactory students, advising is useless."

Excerpt 13: "Students usually do not pay attention to the lecture in the fourth and fifth hours of the class. Students are always sleeping in the fifth hour and are always eating in the fourth hour."

Excerpt 14: "The supervisors outside the classroom may be one of the factors, for those supervisors always take a look at the students' classroom behavior. If it is not under control, the teacher will be informed that classroom management needs to be improved through e-mail."

\subsection{Students' Responses and Opinions Regarding Teacher A's Threats}

Table 2 indicates that when the teacher used indirect threats to avoid the explicit mention of a student, maintaining silence was the most frequent response of the students (36.8\%). However, when the teacher made indirect accusations by questioning a student's unfavorable behavior or direct threats with modified or explicit blame, the most frequent response (10.5\%) was the improvement of behavior. The students tended to improve through the explicit mention of a student's name or number as well as his or her behavior. The students may main-

Table 2. Types and frequency distribution of students' responses toward different threats.

\begin{tabular}{|c|c|c|c|}
\hline Types of Threats & Students' Responses & Occurrence & Percentages \\
\hline \multirow[t]{3}{*}{ Indirect threats } & Silence & 14 & $36.8 \%$ \\
\hline & Deny & 1 & $2.6 \%$ \\
\hline & Rebut & 1 & $2.6 \%$ \\
\hline \multirow[t]{2}{*}{ Indirect accusation } & Improvement & 4 & $10.5 \%$ \\
\hline & Silence & 1 & $2.6 \%$ \\
\hline \multirow[t]{5}{*}{ Direct threats with modified blame } & Improvement & 4 & $10.5 \%$ \\
\hline & No improvement & 1 & $2.6 \%$ \\
\hline & Silence & 1 & $2.6 \%$ \\
\hline & Repeat & 1 & $2.6 \%$ \\
\hline & Deny & 1 & $2.6 \%$ \\
\hline \multirow[t]{4}{*}{ Direct threats with explicit blame } & Improvement & 4 & $10.5 \%$ \\
\hline & Respond & 2 & $5.3 \%$ \\
\hline & Silence & 2 & $5.3 \%$ \\
\hline & No improvement & 1 & $2.6 \%$ \\
\hline Total amount of responses & & 38 & $100 \%$ \\
\hline
\end{tabular}


tain silence after receiving indirect threats for two possible reasons: 1) the students may not know to whom the teacher refers and 2) the students may refuse to express their inner thoughts during class time. However, the responses of the open-ended questionnaire indicated that the students disliked teacher's use of threats in class. Among 49 students, 13 indicated that the use of threats in class may make them feel depressed, increase class tension, and affect classroom atmosphere. Thus, these acts may decrease their motivation to learn in class (see Excerpt 15).

Excerpt 15: "I don't like the teacher's yelling, scolding, or being fierce in class."

\section{Conclusions and Pedagogical Implications}

This study explored English teachers' use of threatening acts in EFL classrooms. In particular, this study investigated the types and patterns of the threatening acts as well as students' perceptions of the teacher's use of threatening acts. According to the results of classroom observation, the teacher interview, and students' open-ended questionnaires, 38 threatening acts and 4 main threat types (indirect threats, indirect accusation, direct threats with modified blame, and direct threats with explicit blame) were noted. Among the four threat types, indirect threats were used most frequently, followed by direct threats with explicit blame, direct threats with modified blame, and indirect accusation. Four patterns of the teacher's use of threatening acts-the mixed use of both direct and indirect threats, the priority of indirect followed by direct threats, the combination of threats with other speech acts, and the reciprocal feature of threats between students and the teacher were evaluated.

Concerning the factors affecting the teacher's use of threatening acts, eight factors were identified: students' unfavorable behavior, students' gender, teacher's role, teacher's personality, teacher's familiarity toward students, teacher's belief, class time, and school standards. Among these factors, the teacher indicated students' unfavorable behavior over time and the supervising system during class time were the main factors leading her to use threatening acts in class.

Regarding students' responses and opinions toward the teacher's use of threats, maintaining silence was the most frequent response of the students after receiving the teacher's indirect threats, whereas for other threat types, improvement of behavior was the most frequent response. Moreover, in their responses to the questionnaire, some students indicated that the use of threats in class may make them feel depressed, increase class tension, and affect classroom atmosphere.

According to the major findings of this study, the following pedagogical implications are proposed. Since politeness can eliminate conflicts and is vital for classroom discourse, EFL teachers are suggested to use polite strategies to in speaking to reduce teacher-student conflict (Šubertová, 2013). First, the teacher tended to adopt both indirect and direct threats in each hour of the class to prevent students' unfavorable behavior. Although indirect threats, which were used 
most frequently, may decrease the conflict between the teacher and the specific students, the effect of such threats seem to be useless as well as a waste of time. This type of nagging may also make students feel depressed and affect classroom atmosphere. In these situations, as suggested by Cole's (1988), the teacher may adopt certain levels of positive politeness strategies to reduce such tension, such as using in-group identity markers to enhance the solidarity between the teacher and students and conveying that the teacher and students are cooperators by offering or promising. Second, regarding the factor affecting the teacher's use of threats, the teacher's threatening acts appeared to mainly originate from the students' repeated unfavorable behavior in class as well as from the pressure of school supervising system. Thus, students are supposed to know that such unfavorable behavior is not allowed in class, and they must take responsibility of their own learning. In this situation, students are should use some negative politeness strategies to fulfill the teacher's negative face wants, such as showing deference or apologizing, so that the teacher is not pressured to continue or intensify the use of threats. Finally, regarding students' responses and opinions toward the teacher's threats, although the teacher expresses that students always obey her requirements after threats or have no further responses or opinions to her threats in class, some students appeared to dislike such threats or nagging because these acts may bring up negative feelings in class. As Senowarsito (2013) indicated, in order to reduce face threatening act in the classroom, teacher could express sympathy, show respect, and establish a friendly facial expressions. The teachers are suggested to pay much more attention to students' inner feelings or affective factors during their teaching process to reduce possible conflicts between the students and the teacher and thus enhance the effectiveness of their teaching to the greatest possible extent.

Even though the present study is conducted to unravel possible types, patterns and the factors of face threatening acts of a junior high school EFL teacher and her students' perceptions towards such acts, the study employs a small sample, including one EFL female teacher and her one intact class only. Future research can involve more EFL teachers with different genders and different levels of students to obtain a comprehensive understanding of face threatening acts in the L2 teaching environment.

\section{References}

Agustina, S., \& Cahyono, Y. B. (2016). Politeness and Power Relation in EFL Classroom Interactions: A Study on Indonesian Learners and Lecturers. International Journal of Language and Linguistics, 3, 92-100.

Allwright, D., \& Bailey, K. M. (1991). Focus on the Language Learner. Cambridge: Cambridge University Press.

Bouchard, J. (2011). Pragmatic Failures and Language Ideologies: Challenges in the Japanese EFL Context. Studies in Culture, 49, 69-141.

Boxer, D. (2002). Nagging: The Familial Conflict Arena. Journal of Pragmatics, 34, 49-61.

Brown, P., \& Levinson, S. (1987). Politeness: Some Universals in Language Use. Cambridge: Cambridge University Press. 
Buck, R. A. (1994). The Empowerment of Discourse Management. Paper presented at 8th Annual International Conference on Pragmatics and Language Learning, University of Illinois at Champaign, Urbana.

Chaudron, C. (1988). Second Language Classroom: Research on Teaching and Learning. New York: Cambridge University Press. https://doi.org/10.1017/CBO9781139524469

Chen, M. T. (2006). An Interlanguage Study of the Speech Act of Disagreement Made by Chinese EFL Speakers in Taiwan. Unpublished Master's Thesis, Koashiung: National Sun Yat-sen University.

Cole, F. L. (1988) Content Analysis: Process and Application. Clinical Nurse Specialist, 2, 53-57. https://doi.org/10.1097/00002800-198800210-00025

Dogancay-Aktuna, S., \& Kamisli, S. (1996). Linguistics of Power and Politeness in Turkish: Revelations form Speech Acts. Paper Presented at the Annual International Linguistics Conference, Ankara, Turkey.

Ewald, J. D. (2007). Foreign Language Learning Anxiety in Upper-Level Classes: Involving Students as Researchers. Foreign Language Annals, 40, 122-142. https://doi.org/10.1111/j.1944-9720.2007.tb02857.x

Graham, S. L. (2007). Disagreeing to Agree: Conflict, (Im)Politeness and Identity in a Computer-Mediated Community. Journal of Pragmatics, 39, 742-759.

Hatipoglu, C. (2007). (Im)Politeness, National and Professional Identities and Context: Some Evidence from e-Mailed "Call for Papers". Journal of Pragmatics, 39, 760-773.

Hiraga, M. K., \& Turner, J. M. (1996). Differing Perceptions of Face in British and Japanese Academic Settings. Language Sciences, 18, 605-627.

Jaszczolt, K. M. (2002). Semantics and Pragmatics: Meaning in Language and Discourse. London: Longman.

Pazey, B. (1994). Testing the Limits of Politeness: Youth Group Talk in a Community Organization. Paper presented to the University Council of Educational Administration, Philadelphia, PA.

Peng, L., Xie, F., \& Cai, L. (2014). A Case Study of College Teacher's Politeness Strategy in EFL Classroom. Theory and Practice in Language Studies, 4, 110-115. https://doi.org/10.4304/tpls.4.1.110-115

Scollon, R., \& Scollon, S. W. (1995). Intercultural Communication: A Discourse Approach. Oxford: Basil Blackwell.

Senowarsito, S. (2013). Politeness Strategies in Teacher-Student Interaction in an EFL Classroom Context. TEFLIN Journal, 24, 82-96.

Simmons, T. L. (1994). Politeness Theory in Computer Mediated Communication. Unpublished Master's Thesis, Birmingham, England: Aston University.

Šubertová, A. (2013). Aspects of Politeness in a Classroom of English as a Second Language. Unpublished Master's Thesis, Prague, Czech: Charles University.

Tannen, D. (1986). Gender and Discourse. Oxford: Oxford University Press.

Tseng, M. C. (2015). An Investigation of Taiwanese Arts Students' English Learning Attitudes. International Journal of Research Studies in Language Learning, 4, 19-32. https://doi.org/10.5861/ijrsll.2014.929

Tsuda, S. (1993). Indirectness in Discourse: What Does It Do in Conversation? Intercultural Communication Studies, 3, 63-74. 
Submit or recommend next manuscript to SCIRP and we will provide best service for you:

Accepting pre-submission inquiries through Email, Facebook, LinkedIn, Twitter, etc. A wide selection of journals (inclusive of 9 subjects, more than 200 journals)

Providing 24-hour high-quality service

User-friendly online submission system

Fair and swift peer-review system

Efficient typesetting and proofreading procedure

Display of the result of downloads and visits, as well as the number of cited articles Maximum dissemination of your research work

Submit your manuscript at: http://papersubmission.scirp.org/

Or contact ojml@scirp.org 